\title{
Article 7. Access to Traditional Knowledge Associated with Genetic Resources
}

In accordance with domestic law, each Party shall take measures, as appropriate, with the aim of ensuring that traditional knowledge associated with genetic resources that is held by indigenous and local communities is accessed with the prior and informed consent or approval and involvement of these indigenous and local communities, and that mutually agreed terms have been established.

Article 7 goes significantly beyond the text of the С вD by establishing an obligation for Parties to develop domestic measures on access to traditional knowledge. Such measures are aimed at ensuring that access to traditional knowledge can only proceed with the PIC or approval and involvement of indigenous and local communities. In line with the other access provisions of the Protocol, ${ }^{1}$ such domestic measures are to provide for the establishment of MAT.

The conceptual difference between State PIC over genetic resources and community PIC over traditional knowledge will be examined below, followed by an interpretation of the qualified language of Article 7.

\section{Community PIC in Relation to Traditional Knowledge}

While the Protocol does not explicitly recognize 'the right' of indigenous and local communities to PIC for granting access to their traditional knowledge, it does so implicitly by requiring Parties to put legislation or other domestic measures in place on community PIC (or approval and involvement) in that regard. Conceptually, Article 7 embodies a 'community PIC requirement' that is separate from and possibly additional to State PIC for access to associated genetic resources, ${ }^{2}$ and that is parallel to the 'community PIC requirement' for

1 Nagoya Protocol Article 6(3)(g). See this commentary on Article 6, section 7.

2 Nagoya Protocol Article 6(1): see this commentary on Article 6, section 3. 
genetic resources 'held' by indigenous and local communities. ${ }^{3}$ While State PIC is premised on the general principle of national sovereignty over natural resources, the requirement for community PIC concerning traditional knowledge is based on international human rights law, namely the right to cultural identity. ${ }^{4}$ From an international environmental law perspective, the rationale for this provision can be found in the preamble to the Protocol, where Parties note

the interrelationship between genetic resources and traditional knowledge, their inseparable nature for indigenous and local communities, and the importance of the traditional knowledge for the conservation of biological diversity and the sustainable use of its components and for the sustainable livelihoods of these communities. ${ }^{5}$

From a broader international law perspective, the Protocol further elaborates on UNDRIP's recognition of the right of indigenous peoples ${ }^{6}$ to maintain, control, protect and develop indigenous peoples' traditional knowledge, ${ }^{7}$ providing for more specific rules about traditional knowledge associated with genetic resources. As discussed in relation to the corresponding Protocol provisions on benefit-sharing arising from the use of traditional knowledge, ${ }^{8}$ these provisions may be considered an implicit recognition of an underlying substantive

3 Nagoya Protocol Article 6(2): see this commentary on Article 6, section 4.2.

4 See ICCPR, Articles 1 and 27; ILO Convention No. 169, Article 2(b); and UnDRIP Articles 3-4. Note also that the Bonn Guidelines, paragraph 37, provide that 'Permission to access genetic resources does not necessarily imply permission to use associated knowledge and vice versa.'

5 Nagoya Protocol 22nd preambular recital, emphasis added.

6 On the rights of local communities under the Protocol and international human rights law, see Introduction to this commentary, section 4.2.

7 UNDRIP Article 31(1) reads: 'Indigenous peoples have the right to maintain, control, protect and develop their cultural heritage, traditional knowledge and traditional cultural expressions, as well as the manifestations of their sciences, technologies and cultures, including human and genetic resources, seeds, medicines, knowledge of the properties of fauna and flora, oral traditions, literatures, designs, sports and traditional games and visual and performing arts. They also have the right to maintain, control, protect and develop their intellectual property over such cultural heritage, traditional knowledge, and traditional cultural expressions.' The un Special Rapporteur on the Rights of Indigenous Peoples considered the recognition of the right to PIC over traditional knowledge and the implicit recognition of indigenous peoples' ownership of traditional knowledge in the Protocol as 'positive aspects' of the adoption of the Protocol: Human Rights Council, "Follow-up report on indigenous peoples," A/HRC/C/21/55, paragraph 59.

8 Nagoya Protocol Article 5(2). See this commentary on Article 5, section 4. 
environmental right of these communities to their traditional knowledge associated with genetic resources. The Protocol is also notable in extending this right to local communities. ${ }^{9}$

As opposed to community PIC over genetic resources held by indigenous and local communities, ${ }^{10}$ the requirement for community PIC over traditional knowledge is put forward in stronger language in the Protocol and is not conditional upon the existence of 'established rights to grant access.' This can be explained by the fact that traditional knowledge is a product, as well as a part and parcel, of the identity and traditional way of life of a community, and therefore national sovereignty cannot be asserted over it."1

As traditional knowledge is therefore seen as 'owned' by the indigenous and local communities concerned and inextricably linked to its identity and way of life, it is essential that Parties to the Protocol develop the relevant implementing measures with the full and effective participation of these communities ${ }^{12}$ and ensure due consideration of their customary laws, protocols and procedures. ${ }^{13}$ How community PIC will be implemented in practice will likely vary from one country to another, or even within the same country, depending on the concerned communities' customary laws, protocols and procedures. As highlighted in the Protocol preamble, in fact, there is a 'diversity of circumstances under which traditional knowledge associated with genetic resources is held or owned by indigenous and local communities' 14 and there are 'unique circumstances where traditional knowledge associated with genetic resources is held in countries, which may be oral, documented or in other forms, reflecting a rich cultural heritage relevant for conservation and sustainable use. ${ }^{15}$

No international process has yet spelt out the specific procedural and substantive requirements for community PIC over traditional knowledge associated with genetic resources, ${ }^{16}$ although guidance developed by СвD Parties

$9 \quad$ See Introduction to this commentary, section 4.

10 Nagoya Protocol Article 6(2) and this commentary on Article 6, section 4-although note the practical difficulty to regulate separately access to genetic resources held by indigenous and local communities and access to traditional knowledge associated with such genetic resources in light of their inseparable nature for indigenous and local communities. See generally on traditional knowledge as part of the collective cultural rights of indigenous peoples: Lenzerini, "Indigenous Peoples' Cultural Rights," op. cit., and Lenzerini and Fraboni, "Indigenous Peoples' Rights, Biogenetic Resources, ” op. cit., 201.

12 See fn. 54 in commentary on Article 5.

13 Nagoya Protocol Article 12(1). See this commentary on Article 12, section 2.

14 Nagoya Protocol, 23rd preambular recital.

15 Nagoya Protocol, 25th preambular recital.

16 In fact, Св Parties have identified the need to develop guidelines in that respect: Св Article 8(j) Working Group, Recommendation 8/4, "How tasks 7, 10 and 12 could best 
provides consensus, soft-law determinations in that regard, in particular in the framework of the Working Group on Article 8(j). ${ }^{17}$ First, the свр Akwé: Kon Guidelines ${ }^{18}$ provide specifications for community PIC, also touching upon issues related to traditional knowledge. According to the Guidelines, the requirement for community PIC implies: consideration of the rights, knowledge, innovations and practices of indigenous and local communities; ${ }^{19}$ respect of customary laws governing ownership, access, control, use and dissemination of traditional knowledge; ${ }^{20}$ the use of culturally appropriate languages and processes; and the allocation of sufficient time and the provision of accurate, factual and legally correct information. ${ }^{21}$ Modifications to the initial proposal require additional PIC of the affected community. ${ }^{22}$ Community PIC may be established through protocols, ${ }^{23}$ consistent with relevant national legislation, on access to and use of traditional knowledge, and assistance by the government in establishing such protocols should be provided by the government if so requested. ${ }^{24}$ Second, according to the СвD Tkarihwaié:ri Code of

contribute to work under the Convention and to the Nagoya Protocol," in "Report of the eighth meeting," Annex 1, paragraph 2(2).

17 These normative developments may be explained by the broad participation that indigenous and local community representatives enjoy in the proceedings of the Working Group on Article 8(j). The 'fullest possible participation' of indigenous and local communities is ensured in all meetings, including in contact groups, by inviting community representatives as Friends of the Co-Chairs, Friends of the Bureau and Co-Chairs of contact groups. However, text proposals by indigenous and local communities' representatives must be supported by at least one Party. See the CBD Article $8(\mathrm{j})$ Working Group, "Report of the seventh meeting," UnEP/CBD/COP/11/7, paragraph 20.

18 Akwé: Kon Guidelines, section F, paragraph 29 reads: 'In the conduct of cultural impact assessments, due consideration should be given to the holders of traditional knowledge, innovations and practices and the knowledge itself. Customary laws governing ownership, access, control, use and dissemination of traditional knowledge, innovations and practices should be observed. Protocols with regard to indigenous and local communities should be followed with regard to the disclosure of secret and or sacred knowledge, including those that may involve public hearings and judicial processes in the courts. In the event of the disclosure of secret and or sacred knowledge, prior informed consent and proper protection measures should be ensured.'

19 Akwé: Kon Guidelines, paragraph 53.

$20 \quad$ Akwé: Kon Guidelines, paragraph 29.

21 Akwé: Kon Guidelines, paragraph 53.

22 Akwé: Kon Guidelines, paragraph 53.

23 Note that the Nagoya Protocol includes the notion of community 'protocols' in Article 12 and 21(1): see discussion on community protocols in this commentary on Article 12, section 2.1.

24 Akwé: Kon Guidelines, paragraph 60, emphasis added. 
Ethical Conduct to Ensure Respect for the Cultural and Intellectual Heritage of Indigenous and Local Communities, ${ }^{25}$ consent should not be coerced, forced or manipulated ${ }^{26}$ In addition, where consent or authority of indigenous and local communities is required with respect to traditional knowledge, it is the right of indigenous and local communities, according to their customary law and procedures, to identify the relevant holders of their knowledge. ${ }^{27}$

Significant work on the concept of free PIC has been undertaken in the context of international human rights processes, although without specific regard to traditional knowledge. International guidance on indigenous peoples' right to free PIC for development projects impacting their land ${ }^{28}$

25 "The Tkarihwaié: Ri Code of Ethical Conduct to Ensure Respect for the Cultural and Intellectual Heritage of Indigenous and Local Communities relevant to the Conservation and Sustainable Use of Biological Diversity" in СвD Decision 10/42, "The Tkarihwaié:ri Code of Ethical Conduct to Ensure Respect for the Cultural and Intellectual Heritage of Indigenous and Local Communities" (20 January 2011) UN Doc UNEP/CBD/COP/10/27 (hereinafter, Tkarihwaié: Ri Code).

26 Tkarihwaié: Ri Code, paragraph 11 reads: 'Any activities/interactions related to traditional knowledge associated with the conservation and sustainable use of biological diversity, occurring on or likely to impact on sacred sites and on lands and waters traditionally occupied or used by indigenous and local communities and impacting upon specific groups, should be carried out with the prior informed consent and/or approval and involvement of indigenous and local communities. Such consent or approval should not be coerced, forced or manipulated.'

27 Tkarihwaié: Ri Code, paragraph 4.

28 In relation, for instance, to the relocation of a community from its traditional lands due to the storage or disposal of toxic waste, or when large-scale development or investment projects have a major impact on traditional territories of indigenous peoples: Human Rights Council, "Promotion and protection of all human rights," A/HRC/12/34, paragraph 47; "Report of the Special Rapporteur on indigenous peoples' rights," A/HRC/24/41, section B. See also work undertaken by the Expert Mechanism, "Final report of the study on indigenous peoples and the right to participate in decision-making. Report of the Expert Mechanism on the Rights of Indigenous Peoples" (17 August 2011) Un Doc A/HRC/18/42. Note further worky by CERD, "Consideration of reports submitted by States Parties under Article 9 of the Convention. Concluding observations of the Committee on the Elimination of Racial Discrimination. India” (5 May 2007) UN Doc CERD/C/IND/Co/19, paragraph 19; "Consideration of reports submitted by States Parties under Article 9 of the Convention. Argentina" (8June 2009) Un Doc CERD/C/ARG/Co/19-20, paragraph 26; "Consideration of reports submitted by States Parties under Article 9 of the Convention. Concluding observations of the Committee on the Elimination of Racial Discrimination. Philippines" (28 August 2009) un Doc CERD/C/PHL/CO/20, paragraphs 22 and 26; "Consideration of reports submitted by States Parties under Article 9 of the Convention. Concluding observations of the Committee on the Elimination of Racial Discrimination. 
may thus be of some use as a source of inspiration in implementing Article 7.29

\section{$3 \quad$ Qualifications}

The language of Article 7 is qualified and attention must be paid to the specific terms used in it. First of all, the obligation to provide for procedures for community PIC and establishment of MAT is limited to traditional knowledge 'held' by indigenous and local communities. The Protocol does not arguably require community PIC for access to traditional knowledge ex situ, for example documented in databases, genebanks or libraries outside community control, if it is no longer held by the community. On the other hand, the Protocol is silent as to the situation in which the traditional knowledge is still held by indigenous and local communities, but also publicly available in other forms. In either case, the non-applicability of the community PIC requirement may not necessarily exclude benefit-sharing, as it can be envisaged that Parties holding traditional knowledge in databases may require benefits in exchange for allowing access to it. ${ }^{30}$ It could also be argued that in cases where no community 'holding' traditional knowledge can be identified, the multilateral benefit-sharing mechanism envisaged by the Protocol ${ }^{31}$ could come into play.

A related question is the actual identification of the relevant communities ('these indigenous and local communities' - emphasis added) that have the right to provide PIC and engage in the negotiation of MAT. This may be particularly problematic where the same traditional knowledge is shared by more than one community located in several Parties: cooperation among relevant Parties, with the involvement of concerned communities, will be needed. ${ }^{32}$

In addition, Article 7 (similarly to the Protocol provision on community PIC on genetic resources held by indigenous and local communities), does not clearly endorse the international human rights-based standard of community

Chile" (7 September 2009) CERD/C/CHL/CO/15-18, paragraph 22; and other reports cited in Human Rights Council, "Follow-up report on indigenous peoples," A/HRC/C/21/55, fn. 14.

29 See this commentary on Article 6, section 4.2.

30 For a discussion on publicly available traditional knowledge, see this commentary on Article 5, section 4.

31 See this commentary on Article 10.

32 Nagoya Protocol Article 11(2). See this commentary on Article 11, section 4. 
PIC, but adds 'or approval and involvement.' As already discussed, ${ }^{33}$ Parties to the Protocol will need to establish some formal processes to engage indigenous and local communities and respect their rights as enshrined in human rights law. ${ }^{34}$ This will be particularly important when community PIC may be embodied in the same decision providing State PIC as a result of communities' participation in government decision-making processes on access. It may raise particular difficulties in situations where under national legislation States have claimed that traditional knowledge is 'the patrimony of the State, ${ }^{35}$ or when traditional knowledge is held in centralized registries or databases outside community control. ${ }^{36}$

Similarly in Article 6, ${ }^{37}$ the reference to 'accordance with domestic law,'38 would not justify an interpretation that the right of community PIC on traditional knowledge is dependent on its recognition in national legislation. It should rather be implemented as referring to the need for Parties to devise implementing measures that functionally fit with other relevant areas of national legislation, while ensuring the respect of relevant international human rights obligations and taking into account communities' customary laws. The reference may also be interpreted as pointing to a facilitative role of the State in situations where indigenous and local communities within their jurisdiction may request support in their interactions with third parties seeking utilization of traditional knowledge. ${ }^{39}$

The due diligence obligation to establish measures providing for community PIC and the establishment of MAT specifically aimed at benefit-sharing with indigenous and local communities is also qualified. It can be assumed that Parties can take any legal, administrative or policy measures, binding or not, 'in accordance with domestic law' and 'as appropriate.' In all events, domestic measures should detail the procedural requirements to obtain the

33 Nagoya Protocol Article 6(2). See this commentary on Article 6, section 4.2.1.

34 See Human Rights Council, "Report of the Special Rapporteur," A/HRC/24/41, paragraph 25; and this commentary on Article 6, section 4.2.

35 E.g., Brazil, Medida Provisória No. 2186-16, 2001, Article 8(2); see discussion in Singh Nijar, "Incorporating Traditional Knowledge," op. cit., 465.

36 See for instance the inventories of intangible cultural heritage created under the UNESCO Convention on Intangible Cultural Heritage, Article 12 (for a brief discussion of the interactions between the Unesco Convention and the Protocol, see this commentary on Article 4, section 2.1).

37 See this commentary on Article 6, section 4.2.

38 Which should be contrasted with СвD Article $8(\mathrm{j})$ language ('subject to national legislation'): Bavikatte and Robinson, “Towards a People's History of the Law," op. cit., 45. Ibid. 
PIC or approval and involvement of the community concerned, and to establish MAT with them, prior to access to their traditional knowledge, taking into consideration customary laws, protocols and procedures of indigenous and local communities. ${ }^{40}$ This is in line with UNDRIP, that expects States to take 'effective measures to recognize and protect the exercise of [traditional knowledge-related] rights', 'in conjunction with indigenous peoples. ${ }^{41}$

The qualifications found in the provision allow Parties to take measures to fit their national circumstances and regulatory traditions, but does not support a potential decision by a Party not to take any measures at all to regulate access to traditional knowledge. This conclusion is supported by the fact that Article 7 does not include the clause found in Article 6 'unless otherwise determined by that Party,' which allows States not to require PIC for access to their genetic resources. ${ }^{42}$ Therefore, it can be argued that even if a State opts for not requiring PIC for access to genetic resources or some categories of them, it is still obliged to develop the procedures required for users to obtain community PIC for access to traditional knowledge associated with such resources.

It should be finally recalled that the in-built flexibility of Article 7 can also benefit indigenous and local communities in the light of the diverse and unique circumstances under which traditional knowledge is held or owned by these communities. ${ }^{43}$ These circumstances inevitably require a variety of legal and other approaches to implement in an effective and culturally appropriate manner Article 7 in different countries, particularly where indigenous and local communities may have conceptual relations to the land that do not fit with statutory concepts of property and use. ${ }^{44}$

\footnotetext{
$40 \quad$ Nagoya Protocol Article 12(1) and this commentary on Article 12, section 2.

41 UNDRIP Article 31(2), emphasis added.

42 See this commentary on Article 6.

43 Nagoya Protocol 23rd and 25th preambular recitals.

44 We are grateful to Geoff Burton for drawing our attention to this point.
} 